\title{
An attempt to identify the evolutionary origin of a novel serotype of Salmonella enterica isolated from harbour porpoises
}

\author{
D. C. OLD, P. B. CRICHTON, A. TAYLOR and H. MATHER*
}

\begin{abstract}
Medical Microbiology, Ninewells Hospital and Medical School, Dundee DD1 9SY and * Scottish Salmonella Reference Laboratory, Stobhill Hospital, Glasgow G21 3UW
\end{abstract}

\begin{abstract}
The isolation since 1991 of a new serotype of Salmonella enterica (antigenic formula 4,12:a:-) from harbour porpoises (Phocoena phocoena) at post-mortem examination raised the question of its evolutionary origin. Representative strains of $S$. enterica serotype 4,12:a:- and strains of eight other serotypes of serogroup 04 with phase-1 flagellar antigen $H$ ' $a$ ' were examined by EcoRI ribotyping, IS200 fingerprinting and PCR-based profiling. Statistical analysis of results of multiple typing showed that strains of Salmonella serotype 4,12:a:- were genetically distant from those of antigenically similar salmonella serotypes, none of which seemed likely to be the progenitor of the 'porpoise' serotype.
\end{abstract}

\section{Introduction}

Most serotypes of Salmonella enterica subsp. enterica (subsp. I) show diphasic variation of flagellar $(\mathrm{H})$ antigens, the alternate expression of which is controlled by a complex switching mechanism [1]. However, certain salmonellae of clinical and epidemiological importance - such as serotypes Enteritidis (1,9, 12:g,m:-) and Typhi (9,12,[Vi]:d:-) - express only one type of flagellar antigen, i.e., they are monophasic. These monophasic serotypes may represent ancestral types which never acquired a second flagellar gene, or the necessary switching mechanism, or they might have originated as mutant strains of diphasic serotypes that had lost either the switching mechanism or the ability to express a second flagellar antigen (usually, but not always, phase 2) [2]. The phylogenetic origin of some monophasic serotypes of Salmonella has been revealed by molecular typing methods [2]. For example, the monophasic $S$. enterica serotype 9,12:1,v:- of serogroup D1 that emerged in several countries was shown to have arisen from an ancestral strain of Salmonella of the diphasic serotype Goettingen [2].

Since 1991, isolates of a new monophasic serotype (antigenic formula 4,12:a:-) of $S$. enterica have been obtained at post-mortem examination from harbour

Received 29 Sept. 2000; accepted 8 Nov. 2000.

Corresponding author: Dr D.C. Old (e-mail: davido@tuht. scot.nhs.uk). porpoises (Phocoena phocoena) caught accidentally in fishing nets or found stranded around the Scottish coastline [3]. This novel 'porpoise' serotype - which should be, but has not yet been, named - comprises at least two clonal groups [4], but information about its mode of transmission and evolutionary origin is lacking. In this study, strains of S. enterica of serotype 4,12:a:- and eight antigenically similar serotypes were examined by ribotyping, insertion sequence (IS200) fingerprinting and PCR-based profiling in an attempt to reveal the possible origin of the 'porpoise' serotype.

\section{Materials and methods}

\section{Bacteria}

The 10 serogroup O4 strains of S. enterica of subsp. I examined (Table 1) included: S932228 and S932732, representative strains of the two clonal lines of the 'porpoise' serotype 4,12:a:- [4]; and eight strains of other rare serotypes with phase-1 flagellar antigen $\mathrm{H}$ 'a' - Arechavaleta, Bispebjerg, Fulica, Hessarek, Huettwillen, Kisangani, Nakuru and Tinda [5]. All strains, including strain NCTC 7375 originally from the National Collection of Type Cultures (Central Public Health Laboratory, Public Health Laboratory Service, 61 Colindale Avenue, London), were from the collection of the Scottish Salmonella Reference Laboratory, Stobhill Hospital, Glasgow. Strains were maintained on Dorset's egg slopes at room temperature $\left(18-20^{\circ} \mathrm{C}\right)$ until they were cultured on blood agar (Oxoid) incubated overnight in air at $37^{\circ} \mathrm{C}$. 
Table 1. Strains of Salmonella examined

\begin{tabular}{|c|c|c|c|c|}
\hline \multirow[b]{3}{*}{ Serotype } & \multirow[b]{3}{*}{ Strain no. } & \multicolumn{3}{|c|}{ Antigenic formula ${ }^{*}$} \\
\hline & & \multirow[b]{2}{*}{$\mathrm{O}$ antigens $^{\dagger}$} & \multicolumn{2}{|c|}{$\mathrm{H}$ antigens } \\
\hline & & & phase 1 & phase 2 \\
\hline$\overline{-7}$ & S932228 & 4,12 & $\mathrm{a}$ & - \\
\hline - & S932732 & 4,12 & $\mathrm{a}$ & - \\
\hline Arechavaleta & S/871826 & $4,[5], 12$ & $\mathrm{a}$ & 1,7 \\
\hline Bispebjerg & $\mathrm{S} / 790913$ & $1,4,[5], 12$ & $\mathrm{a}$ & $\mathrm{e}, \mathrm{n}, \mathrm{x}$ \\
\hline Fulica & $539 \mathrm{~K}$ & $4,[5], 12$ & $\mathrm{a}$ & 1,5 \\
\hline Hessarek & $\mathrm{S} / 923437$ & $4,12,27$ & $\mathrm{a}$ & 1,5 \\
\hline Huettwillen & $7455 / 90$ & $1,4, \overline{12}$ & $\mathrm{a}$ & $1, \mathrm{w}$ \\
\hline Kisangani & NCTC 7375 & $\overline{4,[5], 12}$ & $\mathrm{a}$ & 1,2 \\
\hline Nakuru & 3565 & $1,4,12,27$ & $\mathrm{a}$ & $z_{6}$ \\
\hline Tinda & $267 \mathrm{~K}$ & $\underline{1}, 4,12, \underline{27}$ & $\mathrm{a}$ & $\mathrm{e}, \mathrm{n}, \mathrm{z}_{15}$ \\
\hline
\end{tabular}

* See reference [5].

${ }^{\dagger} \mathrm{O}$ antigens that may be absent are designated as, e.g., [5] and those determined by phage conversion are underlined, e.g., $\underline{1}, \underline{27}$.

${ }^{\text {t}}$ For ease of reference this new serotype, not yet named, is designated in the text as the 'porpoise' serotype.

\section{Ribotyping and IS200 fingerprinting}

One colony from a blood agar culture was inoculated in $10 \mathrm{ml}$ of $\mathrm{L}$ broth [6] in a disposable 20-ml screwcapped plastic tube and incubated with shaking for $18 \mathrm{~h}$ at $37^{\circ} \mathrm{C}$. Bacteria were pelleted by centrifugation for $30 \mathrm{~min}$ at $3000 \mathrm{~g}$ and resuspended for $20 \mathrm{~min}$ at room temperature in formalin $10 \% \mathrm{v} / \mathrm{v}$ in TE buffer (10 mM Tris-HCl, $1 \mathrm{mM}$ EDTA, $\mathrm{pH} 8.0)$ to inactivate cellular nucleases. Cells were washed four times in TE buffer to remove formalin. DNA was extracted by a cetyltrimethylammonium bromide miniprep method [7] and digested to completion with restriction endonucleases EcoRI or Pst I (Pst I does not cut within the IS200 sequence). Strains were examined for their ribotypes and IS200 fingerprints after Southern hybridisation of digested DNA fragments with appropriate digoxigenin (DIG)-labelled probes. Electrophoresis, Southern transfer, DNA probes and hybridisation conditions were as described previously [8]. Line diagrams, representing ribotypes and IS200 fingerprints, were prepared directly from bands present on Xray films with Microsoft Draw for Windows. Given the difficulty of comparing the sizes of high mol.-wt bands, only those bands less than c. 9-14 kb were considered when assessing strain similarity.

\section{PCR-based typing techniques}

PCR fingerprints for all 10 strains were generated from supernates of boiled suspensions prepared directly from bacterial colonies [9]. PCR spacer ribotypes were determined as described previously [10]. RAPD-PCR

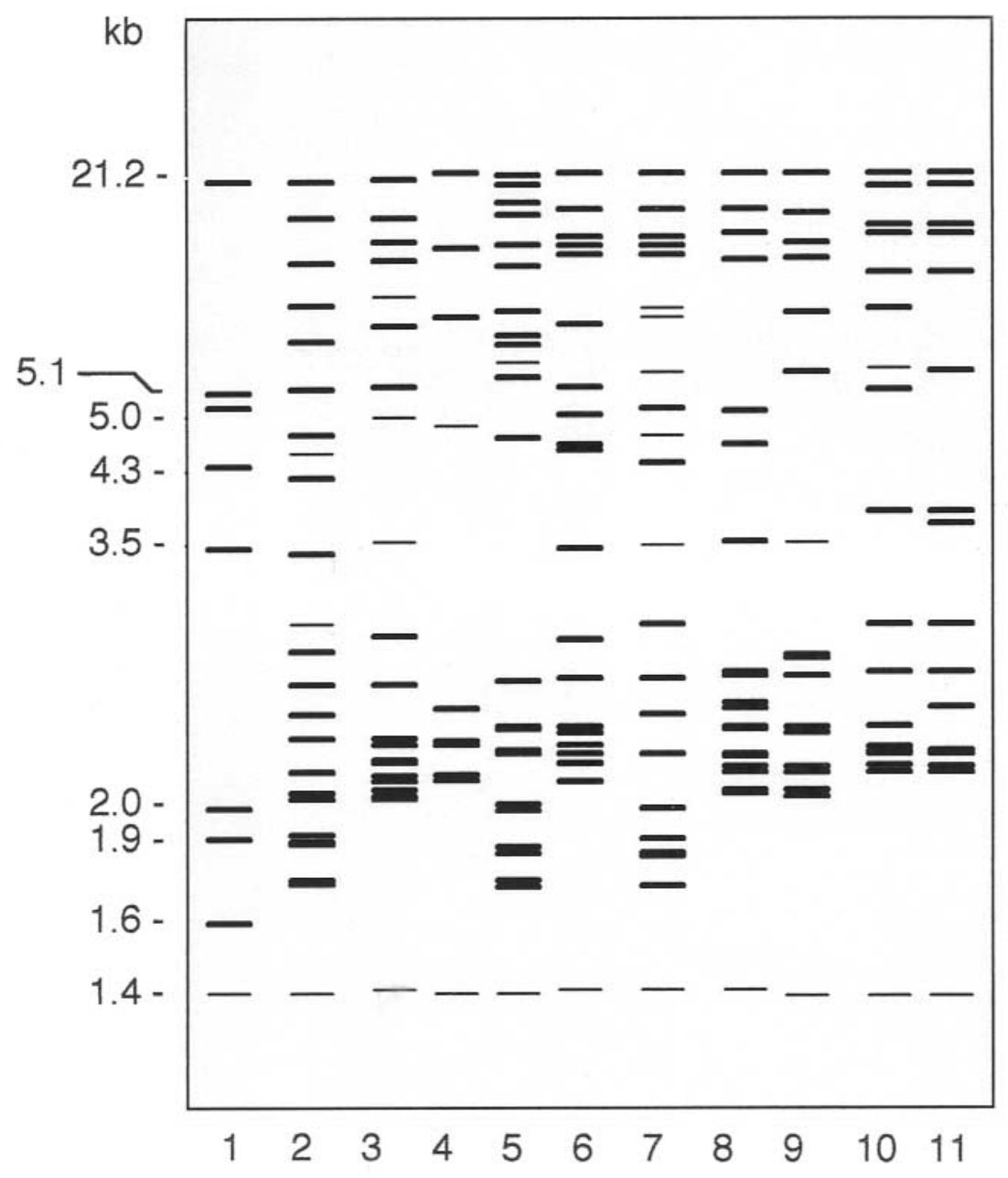

Fig. 1. Line diagram representing EcoRI ribotypes (lanes 2-11) of serotypes of Salmonella serogroup O4 with phase-1 flagellar antigen $\mathrm{H}$ ' $\mathrm{a}$ '. Mol. wt markers $(\mathrm{kb})$ are indicated in lane $\mathbf{1}$. 
profiling was performed with the 10-mer primer 1254 $\left(5^{\prime}\right.$-CCGCAGCCAA-3') [11] and the amplification conditions described by Hilton et al. [12]. Amplification products (7- $\mu 1$ amounts) were separated by electrophoresis at $7-10 \mathrm{~V} / \mathrm{cm}$ through Hi-Pure Low EEO agarose (Biogene, Kimbolton, Cambridge) $2 \% \mathrm{w} / \mathrm{v}$ in TBE buffer ( $89 \mathrm{~mm}$ Tris-HCl, $89 \mathrm{~mm}$ boric acid, $2 \mathrm{mM}$ EDTA) containing ethidium bromide $0.5 \mathrm{mg} / \mathrm{L}$.

\section{Genetic relatedness of serotypes}

Data from all typing methods were used to assess genetic relatedness among strains. Dendrograms were generated with the unweighted pair group mathematical average (UPGMA) in the Multivariate Statistical Package for Windows, version 3.1 (Kovach Computing Services, Pentraeth, Anglesey).

\section{Results}

\section{Ribotyping and IS200 fingerprinting}

When EcoRI-digested DNA of the 10 strains of Salmonella was hybridised with the ribosomal RNA gene probe, 10 ribotypes (E1-E10) were observed (Fig. 1, lanes 2-11). Ribotypes E1-E8 (Fig. 1, lanes 2-9) were obtained for strains of the eight named serotypes. Ribotypes E9 and E10 (Fig. 1, lanes 10 and 11) were those shown by 'porpoise' strains S932732 and S932228, respectively. Although distinct, ribotypes E9 and E10 were related, sharing nine bands of $c .1 .4,2.2$, 2.3, 2.7, 3.1, 3.8, 5.6, 7.4 and $9.3 \mathrm{~kb}$. Ribotypes E1-E8 shared six or less of these nine bands.

When Pst I-digested DNA was hybridised with the IS200 probe, 10 fingerprints were identified (Fig. 2), including that of serotype Nakuru which carried no copies of IS200 (Fig. 2, lane 7). Strains of serotypes Huettwillen and Tinda carried five copies of IS200 (Fig. 2, lanes 5 and 8, respectively). Both strains of the 'porpoise' serotype carried five copies of IS200 and they shared hybridised fragments of c. 2.9 and $3.7 \mathrm{~kb}$ (Fig. 2, lanes 9 and 10). Strains of the other five serotypes examined contained between one copy (serotype Hessarek) and 13 copies of IS200 (serotype Bispebjerg) (Fig. 2, lanes 4 and 2, respectively). Molecular sizes estimated from different gels indicated the presence of a 5.4-kb band in the profiles of serotype Huettwillen and the 'porpoise' strain S932228 (Fig. 2, lanes 5 and 10, respectively).

\section{PCR profiles}

When the strains were analysed by PCR spacer ribotyping, two distinct fingerprints were obtained (data not shown). One profile, shown by strains of serotypes

$\mathrm{kb}$



Fig. 2. Line diagram representing IS 200 profiles (lanes 1-10) of serotypes of Salmonella serogroup O4 with phase-1 flagellar antigen $\mathrm{H}$ ' $\mathrm{a}$ '. Mol. wt markers $(\mathrm{kb})$ are indicated in lane $\mathbf{1 1 .}$ 
Arechavaleta, Bispebjerg, Fulica, Nakuru, Tinda and both strains of the 'porpoise' serotype, comprised two bands of c. 700 and $800 \mathrm{bp}$; the other profile, shown by strains of serotypes Hessarek, Huettwillen and Kisangani, contained an additional band of c. $750 \mathrm{bp}$.

RAPD-PCR generated 10 distinct fingerprints for the 10 strains examined (Fig. 3, lanes 1-12). (Each of the lanes 1 and 2, and 9 and 10 shows preparations of the same strain.) Fingerprints of the 'porpoise' strains S932732 and S932228 were distinguishable but showed many common bands (Fig. 3, lanes 11 and 12, respectively).

\section{Genetic relatedness of strains of antigenically related serotypes}

Individual dendrograms generated from ribotypes, IS200 profiles and RAPD-PCR fingerprints confirmed that strains of the 'porpoise' serotype were themselves highly related at $75 \%, 50 \%$ and $90 \%$, respectively (Fig. $4 a-c)$. The 'porpoise' serotype was shown to be poorly related to the other eight serotypes by ribotyping ( $c$. $40-65 \%)$, IS200 fingerprinting (0-30\%) and RAPDPCR profiling (c. 65-86\%), respectively (Fig. $4 \mathrm{a}-\mathrm{c}$ ). A dendrogram based on data from all typing methods confirmed the close relationship of the two 'porpoise' strains $(79 \%)$, but showed that they were distantly related (c. 54-64\%) to strains of the other eight serotypes examined (Fig. 5).

\section{Discussion}

Molecular typing has enhanced understanding of the epidemiology of salmonella infection by increasing knowledge of the genetic relationships among strains. For example, ribotyping, by consideration of polymorphisms in the highly conserved ribosomal RNA genes, has helped to identify sources and modes of transmission. Ribotypes of strains belonging to the same serotype have common features but differences allow strains responsible for outbreaks and sporadic cases of illness to be distinguished [13-15].

If, as has been argued, ribotypes correlate with multilocus enzyme electrophoresis profiles and reflect genetic lineages rather than short-term genetic evolution [16], they should be useful for the study of bacterial population genetics. In this study, ribotyping confirmed our previous finding [4] that strains of the recently discovered Salmonella serotype 4,12:a:- form

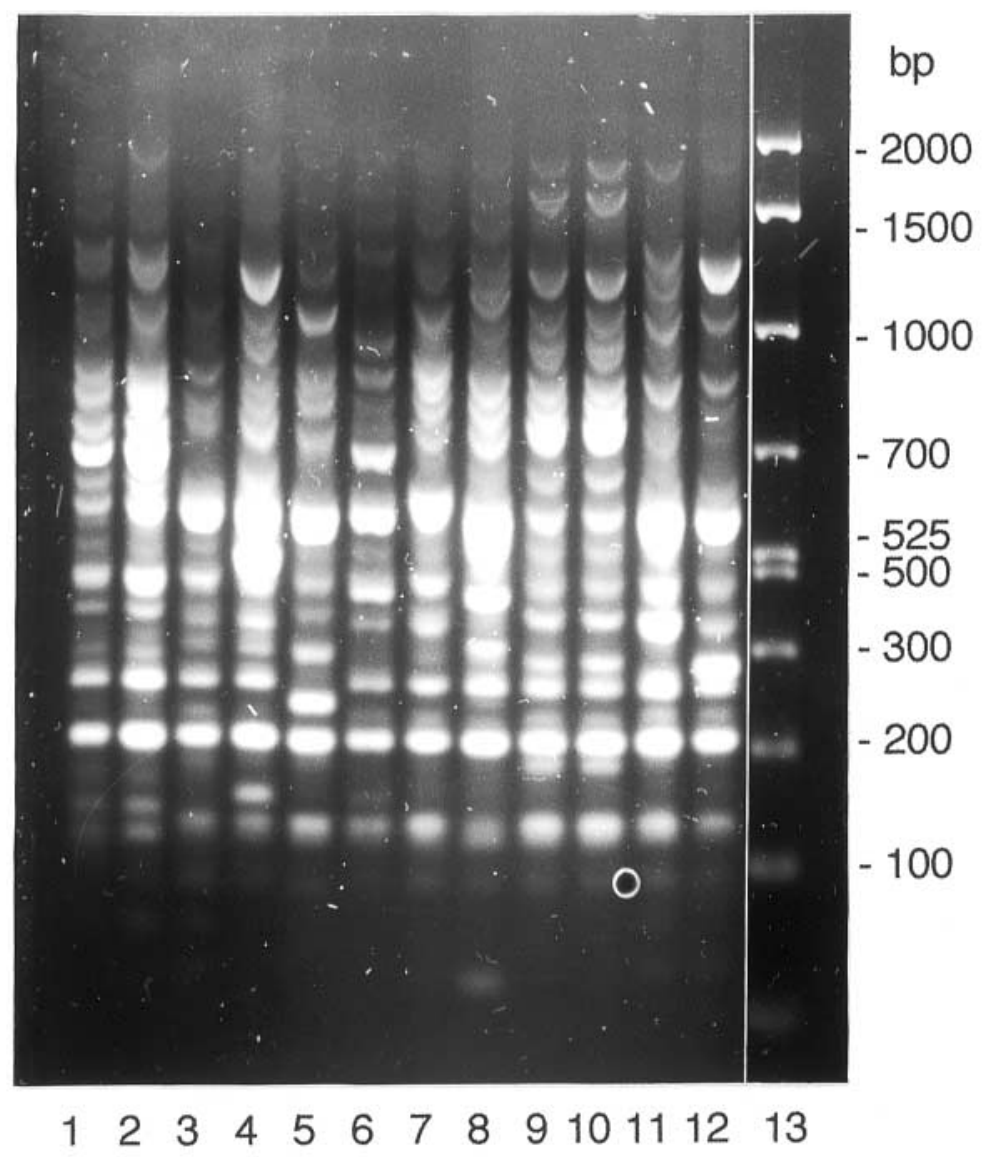

Fig. 3. RAPD-PCR fingerprints (lanes 1-12) of serotypes of Salmonella serogroup O4 with phase-1 flagellar antigen H 'a'. Lanes 1 and 2 (serotype Arechavaleta), and $\mathbf{9}$ and $\mathbf{1 0}$ (serotype Tinda) show different DNA preparations of the same strain. Mol. wt markers $(\mathrm{kb})$ are indicated in lane $\mathbf{1 3}$. 


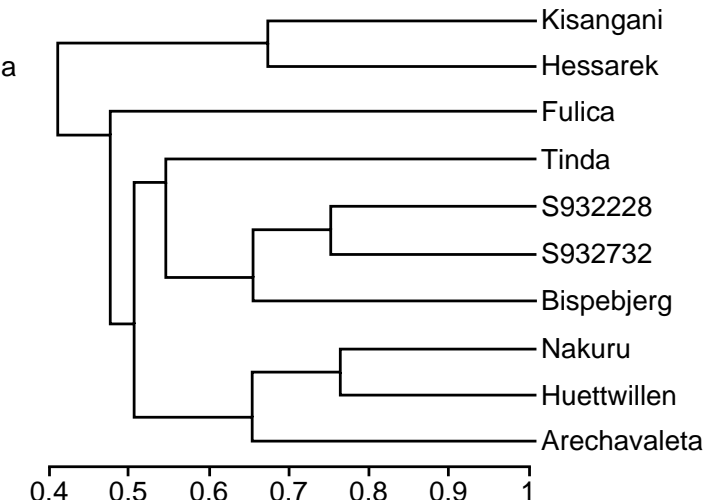

b
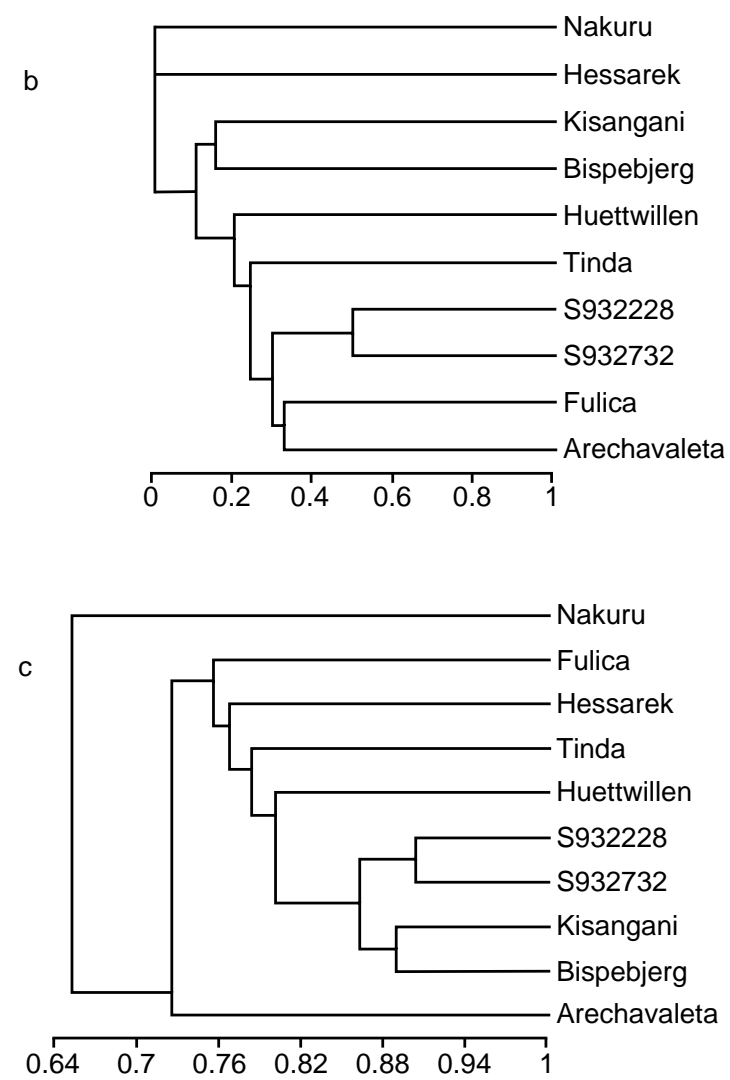

Fig. 4. Dendrograms based on similarity coefficients from: a, EcoRI ribotyping; b, IS200 profiling; c, RAPD-PCR fingerprinting of serotypes of Salmonella serogroup O4 with phase-1 flagellar antigen $\mathrm{H}$ ' $\mathrm{a}$ '. Dendrograms were constructed by the unweighted pairgroup average method in the Multivariate Statistical Package, version 3.1.

a single cluster. However, they are no more closely related to serogroup $\mathrm{O} 4$ strains of antigenically related serotypes (i.e., with phase-1 flagellar antigen $\mathrm{H}$ ' $\mathrm{a}$ ') than they are to strains of serotypes with other phase-1 flagellar antigens (data not shown).

The 708-bp IS200 element has been found in a wide range of salmonellae but it is absent from some serotypes, such as Agona [17]. In theory, IS200 can transpose to other genomic sites but rarely does so in vitro [18]. For that reason, common bands in the IS200 profiles of different strains may indicate a common

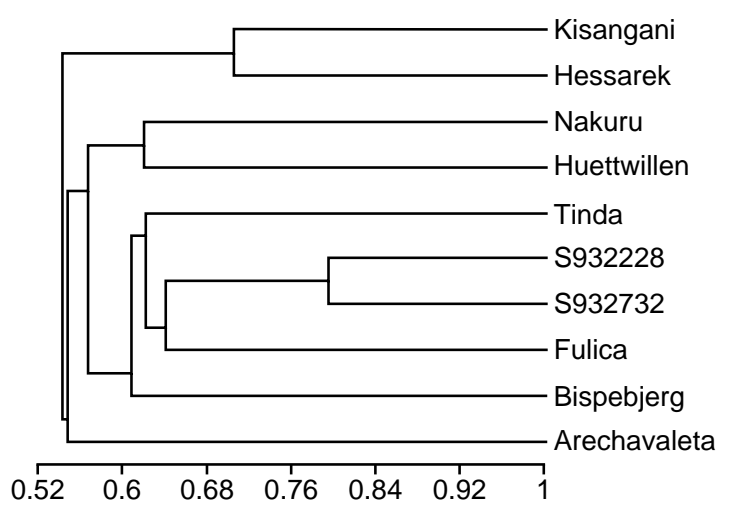

Fig. 5. Dendrogram based on similarity coefficients from combined EcoRI ribotyping, IS200 profiling and RAPDPCR fingerprinting of serotypes of Salmonella serogroup $\mathrm{O} 4$ with phase-1 flagellar antigen $\mathrm{H}$ ' $\mathrm{a}$ '. The dendrogram was constructed by the unweighted pair-group average method in Multivariate Statistical Package, version 3.1.

origin [18] and give insight into the evolution of new serotypes [2]. The IS200 profiles of 41 isolates of Salmonella serotype 4,12:a:- examined previously confirmed the findings from ribotyping - i.e., they showed the existence of two clonal groups [4]. In this study, results from IS200 analysis also supported the conclusions of ribotyping, namely, that the 'porpoise' strains were poorly related to strains of antigenically related serotypes. Indeed, among the strains examined, only the strain of serotype Huettwillen shared a common band with one of the 'porpoise' strains.

PCR spacer ribotyping was poorly discriminatory, but it distinguished strains of serotypes Hessarek, Huettwillen and Kisangani from the other serotypes examined. Ribotyping - a powerful tool for establishing strain relatedness [16] - had already eliminated serotypes Kisangani and Hessarek as likely progenitors of the 'porpoise' serotype. The reliability of RAPD-PCR profiling and, accordingly, its value for the detection of similarities and differences between bacterial strains has been questioned [19]. However, when amplification conditions are carefully controlled, as they were in this study, profiles are reproducible and provide clear strain discrimination. The 'porpoise' strains are closely related $(90 \%)$ but, as already shown by ribotyping and IS200 profiling, none of the antigenically related serotypes examined was a likely progenitor of the 'porpoise' serotype.

Popoff and Le Minor considered that 'serotypes Fulica and Hessarek, with the same global antigenic formula, should not be combined because their biochemical characters are very different' [5]. Results from this study confirmed not only that these two serotypes are genetically distant but also that neither is particularly related to the 'porpoise' serotype (see Figs. 4 and 5). Another Salmonella as rare as serotype Fulica, and originally believed to have the same antigenic formula as the 'porpoise' serotype, is serotype Makoma [20]. However, its antigenic formula was subsequently 
redefined as $\underline{1}, 4,[5], 12, \underline{27}: \mathrm{a}: \mathrm{e}, \mathrm{n}, \mathrm{x}$. The serotype name Makoma has since been withdrawn from the current scheme of recognised salmonellae [5] because it is a member of subsp. II. Serotypes in subsp. II, regardless of their antigenic similarity to the porpoise serotype, were not examined in this study because their biochemical properties are so very different from those of strains in subsp. I [5].

The discovery of Salmonella serotype 4,12:a:- in harbour porpoises was reported only recently [3]. Although epidemiological and phylogenetic information is lacking, it is possible to speculate on the possible evolutionary origins and routes of transmission of this new serotype. In a previous study, Brucella maris, a new species, was reported in various stranded marine mammals including porpoises and dolphins $[21,22]$. The natural hosts of brucellae include cattle, goats, sheep and pigs, in which animals infection of the reproductive tract can lead to abortion or to male sterility [23]. The possible occurrence of widespread brucellosis among marine mammals led to theories about the origins of $B$. maris, namely, that the bacterium had been carried by the ancestors of modern dolphins or porpoises millions of years ago or that it had emerged recently from a source such as agricultural run-off contaminated with faeces of livestock animals.

Salmonella $\mathrm{O} 4$ strains with phase-1 flagellar antigen $\mathrm{H}$ ' $a$ ' are rarely isolated in the UK [24]. High concentrations of bacteria and viruses at marine sites around sewage outfalls are likely to facilitate exchange of genetic material [25], giving rise to variants of recognised microbial species that are adapted to cause infection in sea mammals. Thus, evolutionary convergence of antigenic phenotype and horizontal transfer and recombination of antigen genes between lineages rather than minor mutation may have given rise to this new porpoise-associated serotype of Salmonella. Whilst this study has failed to identify any of the rare serotypes examined as the likely progenitor of serotype 4,12:a:-, the findings support the idea that the 'porpoise' serotype is truly new.

\section{References}

1. Old DC, Threlfall EJ. Salmonella. In: Balows A, Duerden B (eds) Topley \& Wilson's Microbiology and microbial infections, vol 2, Systematic bacteriology, 9th edn. London, Edward Arnold. 1998: 969-997.

2. Burnens AP, Stanley J, Sechter I, Nicolet J. Evolutionary origin of a monophasic Salmonella serovar, 9,12:1,v:-, revealed by IS200 profiles and restriction fragment polymorphisms of the fljB gene. J Clin Microbiol 1996; 34: 1641-1645.

3. Foster G, Patterson IAP, Munro DS. Monophasic group B Salmonella species infecting harbour porpoises (Phocoena phocoena) inhabiting Scottish coastal waters. Vet Microbiol
1999; 65: 227-231.

4. Crichton PB, Henry MS, Old DC. Strain discrimination of a novel serotype of Salmonella from harbour porpoises (Phocoena phocoena) by molecular techniques. Vet Microbiol 2000; 76: $61-70$.

5. Popoff MY, Le Minor L. Antigenic formulas of the Salmonella serovars, 7th revision. WHO Collaborating Centre for Reference and Research on Salmonella. Paris, Institut Pasteur. 1997: 17.

6. Miller JH. Experiments in molecular genetics. Cold Spring Harbor, NY, Cold Spring Harbor Laboratory. 1972: 433.

7. Wilson K. Preparation of genomic DNA from bacteria. In: Ausubel FM, Brent R, Kingston RE et al. (eds) Current protocols in molecular biology 1987-1988, vol 1. New York, Wiley. 1987: 2.4.1-2.4.5.

8. Old DC, Rankin SC, Crichton PB. Assessment of strain relatedness among Salmonella serotypes Salinatis, Duisburg, and Sandiego by biotyping, ribotyping, IS200 fingerprinting, and pulsed-field gel electrophoresis. J Clin Microbiol 1999; 37: $1687-1692$.

9. Liu PY-F, Lau Y-J, Hu B-S et al. Analysis of clonal relationships among isolates of Shigella sonnei by different molecular typing methods. J Clin Microbiol 1995; 33: 17791783.

10. Lagatolla C, Dolzani L, Tonin E et al. PCR ribotyping for characterizing Salmonella isolates of different serotypes. J Clin Microbiol 1996; 34: 2440-2443.

11. Akopyanz N, Bukanov NO, Westblom TU, Kresovich S, Berg DE. DNA diversity among clinical isolates of Helicobacter pylori detected by PCR-based RAPD fingerprinting. Nucleic Acids Res 1992; 20: 5137-5142.

12. Hilton AC, Banks JG, Penn CW. Random amplification of polymorphic DNA (RAPD) of Salmonella: strain differentiation and characterization of amplified sequences. J Appl Bacteriol 1996; 81: 575-584.

13. Stanley J, Baquar N, Threlfall EJ. Genotypes and phylogenetic relationships of Salmonella typhimurium are defined by molecular fingerprinting of IS200 and 16S rrn loci. J Gen Microbiol 1993; 139: 1133-1140.

14. Old DC, Crichton PB, Taylor A, Rankin SC. Phenotypic and genotypic discrimination of strains of Salmonella serotype Eimsbuettel from human and animal sources. J Med Microbiol 1997; 46: 617-622.

15. Old DC, Chisholm SA, Crichton PB. Molecular fingerprinting of Salmonella serotype Glostrup. Lett Appl Microbiol 1999; 29: $156-159$.

16. Hawkey PM. Principles of molecular typing: a guide to the letters. J Hosp Infect 1999; 43 Suppl: S77-S83.

17. Gibert I, Barbé J, Casadesús J. Distribution of insertion sequence IS200 in Salmonella and Shigella. J Gen Microbiol 1990; 136: 2555-2560.

18. Sawyer SA, Dykhuizen DE, Dubose RF et al. Distribution and abundance of insertion sequences among natural isolates of Escherichia coli. Genetics 1987; 115: 51-63.

19. Tyler KD, Wang G, Tyler SD, Johnson WM. Factors affecting reliability and reproducibility of amplification-based DNA fingerprinting of representative bacterial pathogens. $J$ Clin Microbiol 1997; 35: 339-346.

20. Kauffmann F. Weitere Salmonella-species der sub-genera II, III und IV. Acta Pathol Microbiol Scand 1965; 64: 367-372.

21. Foster G, Jahans KL, Reid RJ, Ross HM. Isolation of Brucella species from cetaceans, seals and an otter. Vet Rec 1996; 138: 583-586.

22. Bricker BJ, Ewalt DR, MacMillan AP, Foster G, Brew S. Molecular characterization of Brucella strains isolated from marine mammals. J Clin Microbiol 2000; 38: 1258-1262.

23. Ross HM, Foster G, Reid RJ, Jahans KL, MacMillan AP. Brucella species infection in sea-mammals (letter). Vet Rec 1994; 134: 359.

24. Ministry of Agriculture, Fisheries and Food. Salmonella in livestock production 1996. Addlestone, Central Veterinary Agency. 1997: 11-76.

25. Garrett L. The coming plague: newly emerging diseases in a world out of balance. New York, Farrar, Straus and Giroux. 1994: 561. 